CZECH MYCOL. 63(2): 189-194, 2011

\title{
New records of Dacrymyces ovisporus and Tremella diaporthicola from the Ukraine
}

\author{
VERA F. MALYSheVA ${ }^{1}$, AleXANDER Yu. AKulOV ${ }^{2}$ \\ ${ }^{1}$ Komarov Botanical Institute, Popov street 2, RUS-197376, St. Petersburg, Russia; \\ vf.malysheva@gmail.com \\ ${ }^{2}$ V. N. Karazin Kharkiv National University, Maidan Svobody 4, UA-61077, Kharkiv, Ukraine; \\ bipolaris@mail.ru
}

Malysheva V. F., Akulov A. Yu. (2011): New records of Dacrymyces ovisporus and Tremella diaporthicola from the Ukraine. - Czech Mycol. 63(2): 189-194.

The present paper deals with new records of the heterobasidioid fungi Dacrymyces ovisporus Bref. and Tremella diaporthicola Ginns et M.N.L. Lefebvre in Europe. The taxonomical status of these species is considered and detailed descriptions and illustrations of specimens are given.

Key words: heterobasidiomycetes, new records, Dacrymyces ovisporus, Tremella diaporthicola, Ukraine.

Malysheva V. F., Akulov A. Yu. (2011): Nové nálezy druhů Dacrymyces ovisporus a Tremella diaporthicola na Ukrajině. - Czech Mycol. 63(2): 189-194.

V článku jsou publikovány nové evropské nálezy heterobasidiomycetů Dacrymyces ovisporus Bref. a Tremella diaporthicola Ginns \& M.N.L. Lefebvre včetně podrobných popisů, obrázků a taxonomické diskuse.

\section{INTRODUCTION}

In this article we present information on two rare heterobasidioid species, Dacrymyces ovisporus Bref. and Tremella diaporthicola Ginns \& M.N.L. Lefebvre, found for the first time in the Ukraine.

Dacrymyces ovisporus is known to be a saprotrophic species forming its basidiocarps only on wood of gymnosperms. It was described by J. O. Brefeld from Germany at the end of the nineteenth century and is regarded to be a rather rare but widespread species. There are only a few collections known from a number of European countries, including Austria (Wojewoda 2002), Bulgaria (Denchev \& Assyov 2010), Czech Republic (Wojewoda 2002), Estonia (Raitviir 1967), Finland (Ulvinen et al. 1981), Norway (Torkelsen 1972), Poland (Wojewoda 2002, 2003), Portugal (Dueñas 2002), Scotland (Reid 1974), Spain (Dueñas 2002), and Sweden (McNabb 1973). It is known that R. J. Bandoni (1963) also found it in Canada. Tremella diaporthicola is mycoparasitic fungus associated with stromata 
of pyrenomycetes collected mainly from Canada and North America (Ginns \& Lefebvre 1993). Identifying our material, we have faced severe nomenclatural confusion concerning this species and its synonyms, which needs to be further disentangled.

\section{MATERIALS AND METHODS}

The morphological characters described below were studied in both fresh and dried specimens. Material was collected in the Ukraine in the years 2004 and 2009. Microscopic characters were examined in a 5\% solution of $\mathrm{KOH}$ and $1 \%$ Congo Red in concentrated $\mathrm{NH}_{4} \mathrm{OH}$, sometimes in Cotton Blue. Microstructure dimensions were based on the measurements of not less than 20 elements of the same type. All collections studied are deposited in the Mycological Herbarium of the V. N. Karazin Kharkiv National University [CWU (Myc)] and in the Komarov Botanical Institute (LE).

\section{REsults AND DISCUSSION}

Dacrymyces ovisporus Bref., Unters. Gesammtgeb. Mykol. (Leipzig) 7: 158 (1888).

Figs. 1, 2

Basidiocarps small, gregarious, at first pustulate, each pustule $2-4 \mathrm{~mm}$ in diam., becoming convoluted, attached to substratum by a central point; consistency firm-gelatinous; orange or amber when fresh and dark amber or dark brown when dry.

Internal hyphae smooth, thin-walled, gelatinised, with clamp connections. Hymenium composed of dikaryophyses and basidia. Dikaryophyses simple, cylindrical, thick-walled, with clamp connections throughout their length. Basidia cylindrical or subclavate, with two long sterigmata and basal clamp connections, $40-50(70) \times 5-10 \mu \mathrm{m}$. Basidiospores large, subglobose to broadly oval, hyaline or tinted, thin-walled, apiculate, mostly with thin septa, but becoming muriform by formation of transverse, longitudinal and oblique septa at maturity, 14-20 $\times 8-11$ $\mu \mathrm{m}$, germination by germ tubes or conidia.

Habitat. On wood of coniferous trees.

General distribution. North America, some European countries (see Introduction).

Notes. D. ovisporus is mainly characterised by large subglobose or broadly oval, muriform spores. It is a rare species in Europe. 


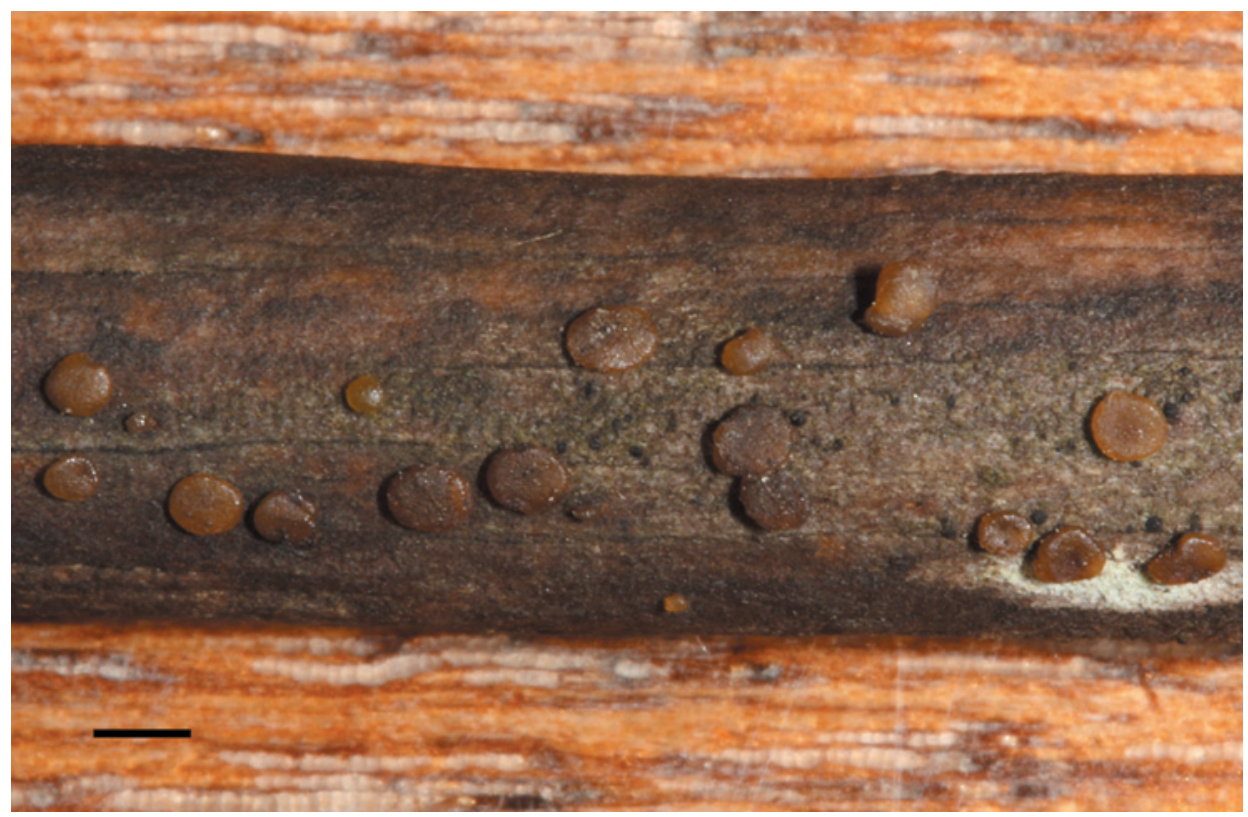

Fig. 1. Basidiocarps of Dacrymyces ovisporus (scale bar $1 \mathrm{~mm}$ ).
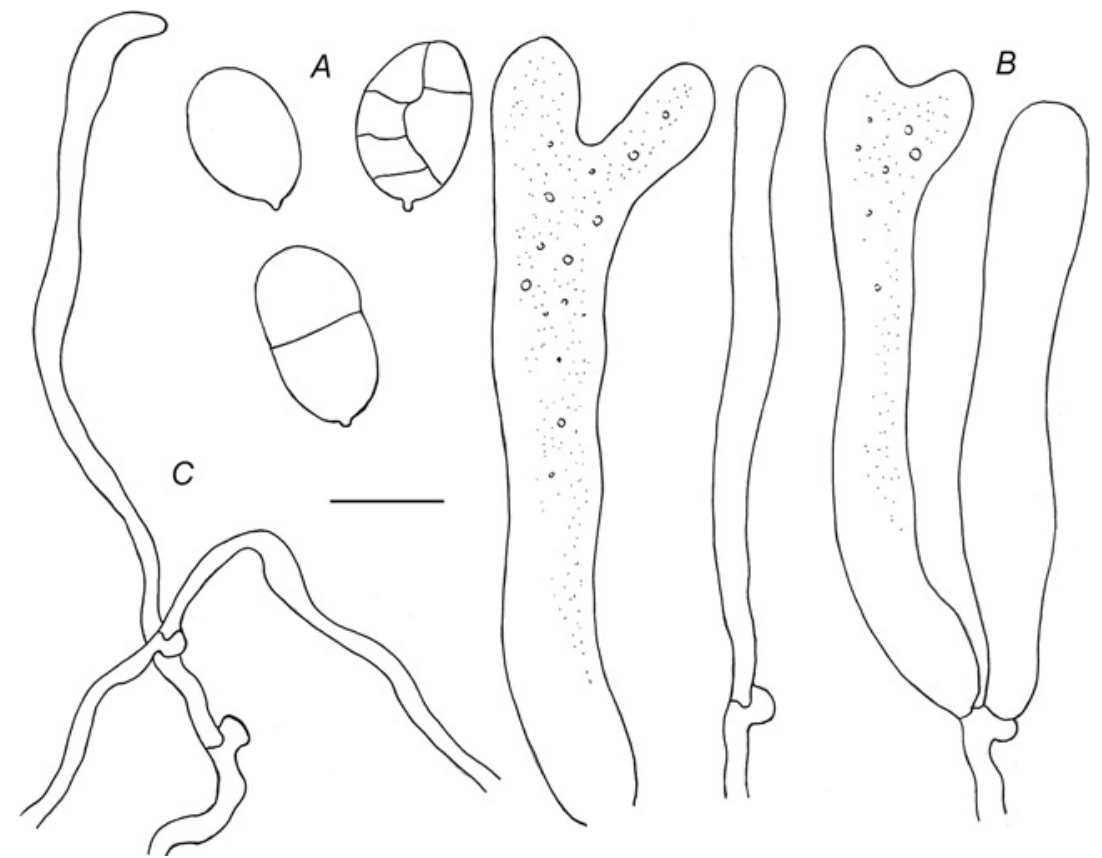

Fig. 2. Dacrymyces ovisporus (LE 262830): A - basidiospores, B - basidia and dikaryophyses, C hyphae (scale bar $10 \mu \mathrm{m}$ ). 


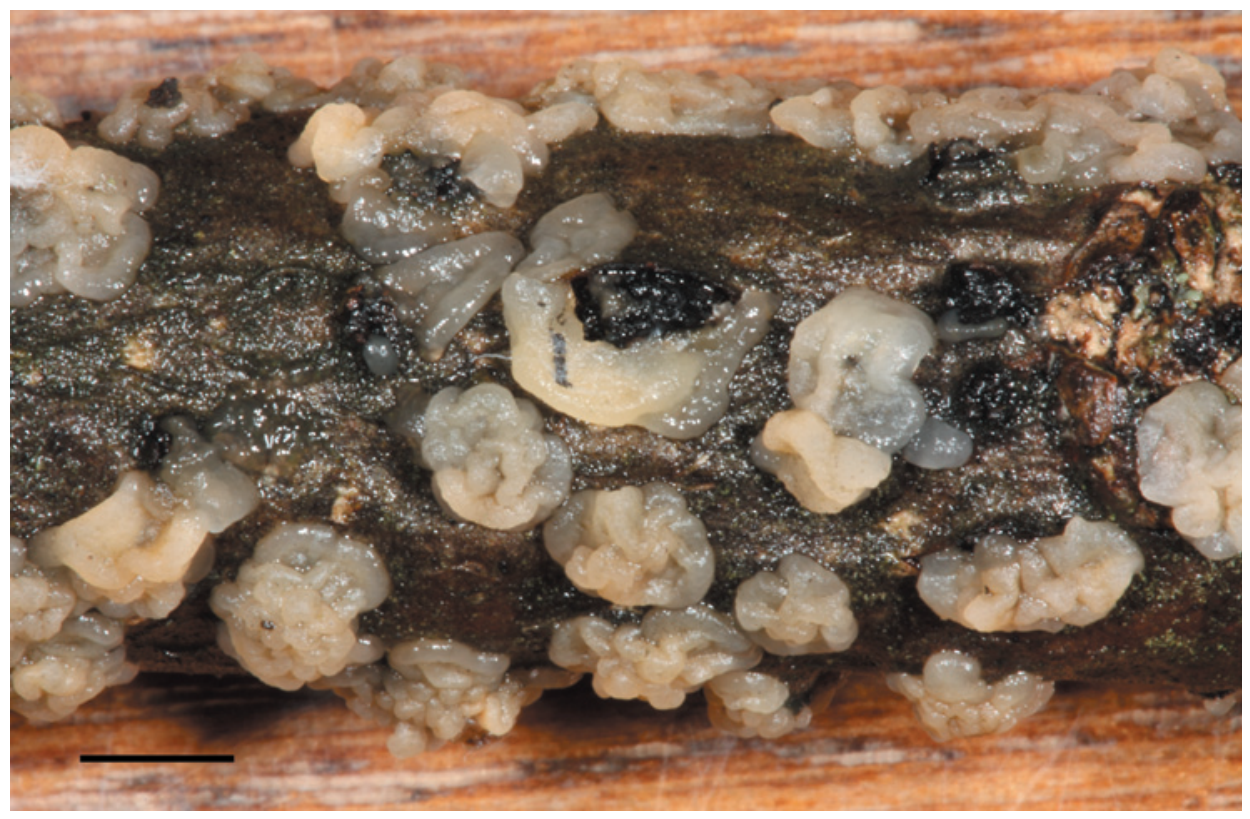

Fig. 3. Basidiocarps of Tremella diaporthicola (scale bar $2 \mathrm{~mm}$ ).

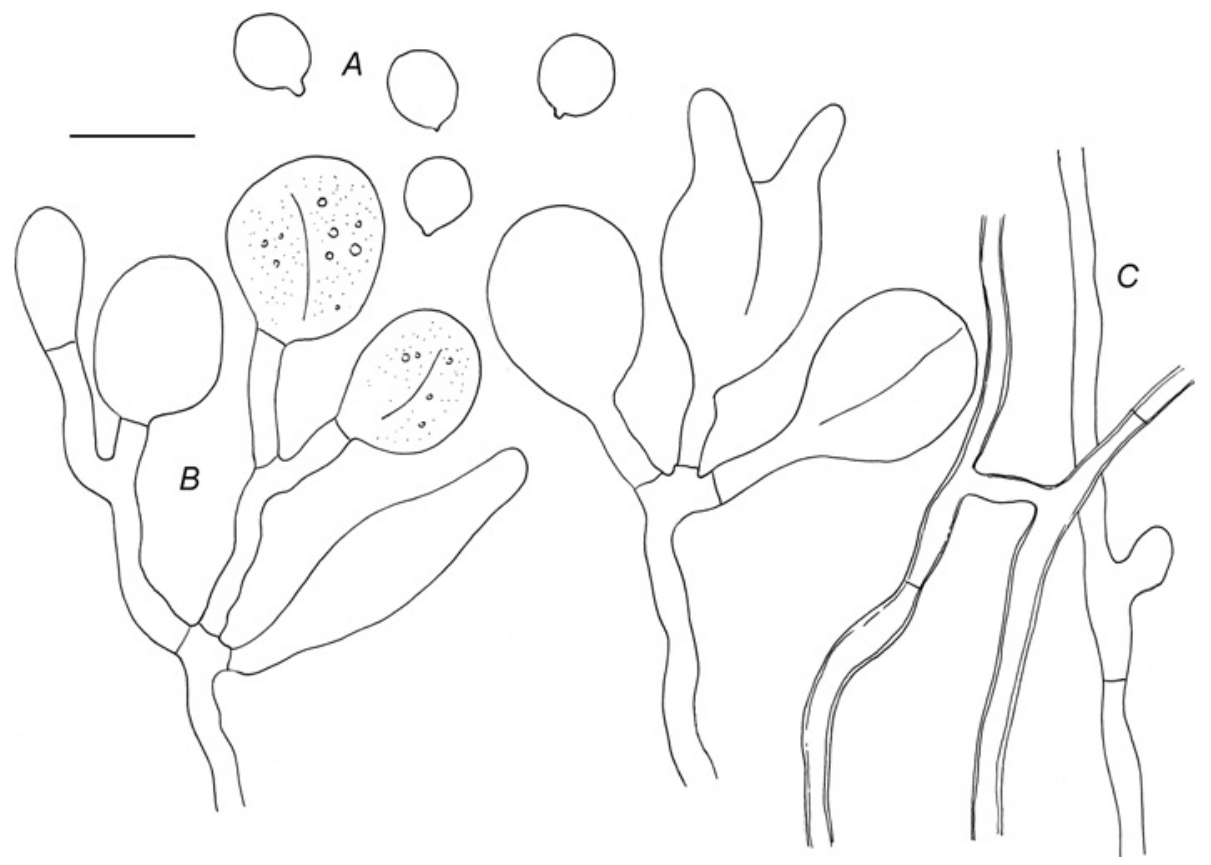

Fig. 4. Tremella diaporthicola (LE 262837): A - basidiospores, B - basidia, C - hyphae (scale bar $10 \mu \mathrm{m})$. 
Sp e cim en s ex a min e d. Ukraine. Southern coast of Crimea: Greater Yalta, Mys Martyan Nature Reserve, juniper forest, on twigs of Juniperus excelsa Bieb., 30 Jun. 2004, col. S. Klitmova, det. V. Malysheva (CWU (Myc) 4093; LE 262830). - The same place, on twigs of Juniperus excelsa, 01 Jul. 2004, col. A. Bereznicky, det. V. Malysheva (CWU (Myc) 4092; LE 262836).

Tremella diaporthicola Ginns et M.N.L. Lefebvre, Mycol. Mem. 19: 169 (1993). = Sebacina globospora Whelden, Rhodora 37: 126. 1935.

Figs. 3, 4

Basidiocarps well-developed, hemispherical at first, originating from the stromatal cavities of sphaeriaceous fungi, becoming effuse and convoluted, from 6 to $10 \mathrm{~mm}$ in diam., broadly attached to substratum by a central point, surface smooth; consistency gelatinous; hyaline or watery grey when fresh, usually becoming brownish when dry.

Internal hyphae narrow, thin-walled or slightly thick-walled, hyaline, 2 to $3 \mu \mathrm{m}$ in diam., without clamp connections. Gloeocystidia rare, 28-35 × $7 \mu$ m when mature. Basidia in clusters, ovate, broad-ellipsoid or pyriform, with short stalks, becoming longitudinal septate, $13-20 \times 12-15 \mu \mathrm{m}$. Basidiospores subglobose or globose, hyaline, thin-walled, apiculate, 5.5-7(8) $\times 5.5-7 \mu \mathrm{m}$.

$\mathrm{H}$ a bitat. Parasitic on the stromata of Diaporthe and similar pyrenomycetes.

General distribution. North America (type specimens), Ukraine (this article).

N ot e s: T. diaporthicola differs from T. globispora by lacking clamps. The nomenclatural position of this taxon remained uncertain for a long time because of scanty original descriptions given by the authors.

Sebacina globospora was firstly described from North America by Whelden (1935). Martin (1952) synonymised Sebacina globospora Whelden with T. tubercularia Berk., having found them conspecific. Reid (1970) examined the neotype of Tremella tubercularia at Kew, plus additional Berkeley collections, and found them to be the ascomycetous anamorph now known as Coryne albida (Berk.) Korf et Cand. Therefore, according to Reid, Tremella globispora D.A. Reid 1970 is the correct name for the clamped Tremella species previously known as T. tubercularia sensu auct.

Much later Ginns \& Lefebvre (1993) proposed a new name for unclamped Sebacina globospora Whelden - Tremella diaporthicola Ginns et Lefebvre based on the following arguments: "McGuire after studying the type, concluded - to be referred to Tremella. The apparent mycoparasitic habit of this fungus and McGuire's conclusion after morphological study are sufficient evidence to transfer the name to Tremella. A new epithet is necessary because there already is a T. globispora D.A Reid 1970" (p. 169). 
Spe cim en s ex a min ed. Ukraine. Donetsk region: Svyatye Gory National Park, Teplinskoe forest, oak-wood, on stromata of Diatrypella sp., 19 Nov. 2009, col. A. Akulov, det. V. Malysheva (CWU (Myc) 4052; LE 262837).

\section{ACKNOWLEDGEMENTS}

We are very grateful to our reviewers for useful advice and valuable comments. This study was partly funded by the Russian Foundation for Basic Research (project N 10-04-01189-a).

\section{REFERENCES}

BANDONI R.J. (1963): Dacrymyces ovisporus from British Columbia. - Mycologia 55: 360-361.

DENCHEV C.M., AssYov B. (2010): Checklist of the larger basidiomycetes in Bulgaria. - Mycotaxon 111: $279-282$

DUEÑAS M. (2002): Annotated List of heterobasidiomycetous fungi for the Iberian Peninsula and Balearic Islands. - Bibliotheca Mycologica 196: 1-90.

GINNS J., LEFEBVRE M.N.L. (1993): Lignicolous corticioid fungi (Basidiomycota) of North America. Mycologia Memoirs 19: 1-247.

KENNEDY L.L. (1958): The genus Dacrymyces. - Mycologia 50(6): 896-915.

MARTIN G.W. (1952): Revision of the North Central Tremellales. - Univ. Iowa Stud. Nat. Hist. 19(3): 122.

MCNABB R.F.R. (1973): Taxonomic studies in the Dacrymycetaceae VIII. Dacrymyces Nees ex Fries. New Zeal. Journ. Bot. 11: 461-524.

RAITVIIR A. (1967): A list of Estonian Heterobasidiomycetae (Auriculariales, Tremellales, Dacrymycetales). - Loodusuur. Seltsi Aastar. 58: 43-50.

REID D.A. (1970): New or interesting records of British hymenomycetes. IV. - Transactions of the British Mycological Society 55(3): 414.

REID D.A. (1974): A monograph of the British Dacrymycetales. - Transactions of the British Mycological Society 62(3): 433-494.

TORKELSEN A.-E. (1972): Gelésopper. - 102 p. Oslo.

Ulvinen T., OHenoja E., AHTI T., Alanko P. (1981): A check-list of the fungi (incl. lichens) of the Koillismaa (Kuusamo) Biological province, N.E. Finland. - 72 p. Oulu.

WHELDEN R.M. (1935): Observations on the cytology of Sebacina globospora n. sp. - Rhodora 37: 121-128.

WOJEWODA W. (2002): Dacryomyces ovisporus (Dacryomycetales, Basidiomycetes) new to the Czech Republic. - Czech Mycol. 54(1-2): 11-17.

WOJEWODA W. (2003): Checklist of Polish larger basidiomycetes. - 812 p. Kraków. 